\title{
THE VITAL CYCLE OF THE ORGANIZATIONAL CULTURE OF THE TRADING ENTERPRISES
}

Approaches are already analyzed for interpretation of the essence of the concept of the organizational culture. It was offered the author's concept of the designation stage of the vital cycle of organizational culture on the trading enterprises. By the export, evaluation methods defined the groups for identifying the effectiveness of the enterprise's activity and the level of the accomplishment of the organizational culture. In this article, there are ways which are defined for the formation of the organizational culture. Appeared the algorithm of the methodical approach for the program of the formation balanced organizational culture of the trading enterprises. Already formed the main recommendations of the increasing the effectiveness of the activity of the enterprises by the trading ways for the refinement of the organizational culture.

Key words: the vital cycle, the organizational culture, retail, the enterprise, trade, the matrix, (-well) balanced.

Droblem statement. In terms of the competitive circumstance special topicality for the retailed enterprises is being attained by the organizational culture. Delaying of the temps of increasing of the internal market, delaying of the purchasing stirring of the consumers causing exacerbation of systemic contradictions on the activities of the trading enterprises. Erroneous orientation of the management of the enterprises for the implementation of the outdated management tools causes the delaying of the effectiveness of the trading enterprises, furling the programs of the socio-economic development, destabilization of the internal processes and destruction of the hierarchy of the organizational values.

During the hard economic conditions, the key question for management of the trading enterprises is searching of the new sources for the providing competitive advantages, where the organizational culture can be the factor, which will be positively influence on their incarnation to activity. Nowadays there are different models of origination and organizational culture are functioning. But majority of the models determining only the steps of formation organizational culture, without providing the real recommendations concerning the controlling them. That's why appearing necessity of searching new effective methods non-price competition that's causing the need of implementation of conception of the vital cycle of the organizational culture.

Analysis of recent researches and publications. The most significant contributions for the research the questions which are concerning the formation of the organizational culture of enterprises, did such domestic and foreign scientists like: O. Bala, L. Balabanova, E. Brown, R. Griffin, D. Drennan, G. Zaharchin, S. Ipatov, K. Cameron, V. Konovalova, R. Quinn, D. Lifintsev, A. Mazaraki, E. Malinin, G. Mintzberg, G. Morgan, G. Moshek, M. Pakanovskyy, T. Persikova, A. Radugin, V. Sate, V. Spivak, T. Solomandina, O. Tikhomirova, M. Thompson, R. Feschur, O. Harchishina, E. Shane, H. Schwartz, G. Hofstede, Ch. Handy etc.

We should commend to the scientific and practical significance of these works and high level researches, but her results not always can be implemented to the activity of the domestic enterprises. Except this, the questions of the vital cycle of the organizational culture nowadays not enough consideration.

Aim of the article. Thereby, the aim of the researching is the analyze existing interpretations of the meaning of "organizational culture" and on this base is going the developing of the conception her vital cycle. 
Presentation of the basic research data. Nowadays on the global market the offer is more than demand on the goods and services and the meaning of the innovation became almost the illusion. Under such circumstances it's hard to create something new, for catching the attention of the freakish consumer.

Theoretical aspects of the organizational culture highlighted in the works of S.A. Ipatov, where on his point of view, this is «...the collectivity of the main convictions, which are formed by themselves, established and formed, established or developed in accordance to the group until it learns how to solve the problems of adaptation for the external circumstance and internal integration, which are appeared quite effective, for them being valuable and that's why transmitted to the new names like the right vision of apprehension, mentality and position up to the specific problems» [1, p. 241]. Organizational culture signals the creative activity, which is implemented to values, traditions, norms and based on materialized traditions. In turn, E. Brown determines the organizational culture as «... set of beliefs, values and appropriated the methods of determining the specific problems, which are formed while the vital organization and that's having a tendency in different material forms and in behavior of the members of the organization" [10, p. 84].

Deserving our attention the point of view S.O. Solomandina, who are under the organizational culture understands «... social and spiritual sphere of enterprise, which is forming under the influence of material and intangible, express and hidden, perceived and unconscious processes and effects, which are determine the unity of the philosophy, ideology, values, approaches to the solving problems and behavior of the staff of the enterprise and allowing to the organization ascend up to the success» $[6, p .45]$. When O.V. Harchyshyna, thinks that the organizational culture «... is the basic element of the internal circumstance of the organization, which provides the optimal internal integration and external adaptation and determines interpersonal cooperation of members of the organization while the process of her evolutional development and purposeful influence of the leadership, including the implicit (the conviction, documentary and regulatory support of the administration, symbols, traditions, image, brand), components» $[9$, p. 62].

Something under another angle of view determines the essence of the organizational culture G. Zaharchyn: "his is... treated as a system of relations, which are appeared on the organization on the basics of the accepted values, basic ideas and ethics, required for the determining her mission» [3, p. 86]. Suggested definition is different from the existing by the displaying not only the main nucleus of the culture but as an active aspect of the organizational culture, whereas values, norms and rules of conduct are passive by themselves if they evident through the system of the relations. The bearer of the values and culture is a human, which enters into relations with the others that's why they are appearing only in the special activities.

On results undertaken a study of scientific sources, practice of work of enterprises of trade and use having a special purpose, the system and processing approaches the specified determination of concept "organizational culture of trading enterprise", under that understand totality of formal and informal mutual relations, material and non-material values, rules and methods, actions and communications between all participants of activity enterprises that form key competences and provide the long-term competitiveness of enterprises, is offered $[5$, p. 20]. It creates pre-conditions for forming of totality of ideas, principles and methods that must provide progressive development of enterprise in the forecast limits of effectiveness and efficiency of his activity. Forming of organizational culture of trade enterprise envisages combining and combination of different organizational processes. In most theories in the vital loop distinguish four stages of development, that differ in one from other the aims of marketing measures, basic type of consumers of commodity, pricing, assortment. For this reason, methodological basis of research of evolution of organizational culture on the enterprises of retail is a theory of life cycle. Development of life cycle takes place after such stages: origin of idea (initial stage in forming of organizational culture, absence of the clearly set forth values, aims of enterprise, rules of behavior of personnel); «first steps» (becoming 
of organizational culture, present risks, developments of primary priority values); forming (process of search of individual brand name style); modernization (is an analysis of competitive edges and quality of external attributes of organizational culture, and also determination of attitude toward them of consumers, workers, business partners; stowage of strategic plans for perfection of organizational culture; forming of corporate values, rules and codes of conduct is on an enterprise); self-affirmation (claim of brand name style, management an image and reputation, there is the developed system of public welfare of personnel, generating ideas, realization of researches and introduction of innovations); "aristocracy» (ideal state of organizational culture); conservatism(the difficult multi-level checking, obstacle system is for new ideas; absence of independence is in a decision-making and, as are sult, individual responsibility); eventual point (of non-acceptance of organizational culture by a personnel, especially new employees; an organizational culture doesn't answer the requirements of enterprise, does not execute the functions, arrives at an eventual point, there is a necessity of her renovation) [2, p. 165].

The analysis of life cycle of organizational culture of enterprises of the retail it is expedient to conduct on the basis of the generalized indexes of the state of him subjective and objective attributes. For determination of the stage of life cycle of organizational culture offer an own matrix. As well as all classic models of the strategic planning, the matrix of determination of the stage of life cycle of organizational culture shows a two-dimensional table, where the axis of $\mathrm{X}$ represents the level of perfection of brand, and an axis of $\mathrm{Y}$ is efficiency of activity of enterprise. The marked criteria are estimated upon settlement of Sef (1) and Sdb (2):

$$
S_{e f}=0,25 \cdot S_{f e p}+0,2 \cdot S_{i p}+0,15 \cdot S_{t z}+0,2 \cdot S_{u t p}+0,2 \cdot S_{s h f},
$$

Where: Sef - the effectiveness of the activity of the enterprises;

Sfep - it is the state of the financial and economical indexes of enterprise;

Sip - is the informational politics on the enterprise;

Stz - is the technical supplement on the enterprise;

Sutp - the administration of the human resources on the enterprise;

$\operatorname{Ssh} f$ - is the innovational activity on the enterprise;

0,$25 ; 0,2 ; 0,15 ; 0,2 ; 0,2$ - appropriate coefficients of corresponding indicators.

$$
S_{d b}=0,25 \cdot S_{a b p}+0,13 \cdot S_{a p}+0,22 \cdot S_{i i s}+0,22 \cdot S_{y o}+0,18 \cdot S_{u p},
$$

Where: $S d b$ - the level of perfection of organizational culture;

$S a b p$ - state attributes of organizational culture, public relations, marketing and advertising;

Sap - state of associative space;

Siis - state image, identity, brand perception and organizational culture;

Syo - state of quality of service;

Sup - state of management potential;

0,$25 ; 0,13 ; 0,22 ; 0,22 ; 0,18$ - appropriate coefficients of corresponding indicators.

The set indexes of efficiency of activity of enterprise and level of perfection of organizational culture it is suggested to estimate the method of expert estimations from 0 to 5 points, where 0 is absence of the state, 5 is the ideal state [1, p. 77].

For determination of points it is expedient to create the group of experts, to that the leading specialists of enterprise will be brought over. On the generalized results the working form of estimation of efficiency of activity of enterprise (table. 1) and level of perfection of organizational culture (table. 2) is filled.

In the process of information collection and aggregation for an enterprise performance appraisal, the experts, at first, choose the factors of ascendancy. According to the 
results of investigation of their dominance on organizational culture it is given finding on reasonability of their grouping with the view of more complete identification of the existent reserves of economic growth what can be in the form of the consistent matrix $[1$, p. 78$]$.

Table 1

Working form evaluating the effectiveness of the company

\begin{tabular}{|c|c|c|c|c|}
\hline The index & Components & $\begin{array}{l}\text { Criteria } \\
\text { of } \\
\text { validity } \\
\mathbf{P}_{\mathbf{j}}\end{array}$ & $\begin{array}{c}\text { Estimate } \\
\mathbf{T}_{\mathbf{j}} *\end{array}$ & $\begin{array}{l}\text { Significance of } \\
\text { the factors } \\
\lambda \mathbf{j}=\mathbf{P}_{\mathrm{j}}^{*} \mathbf{T}_{\mathrm{j}}\end{array}$ \\
\hline $\begin{array}{l}\text { Financial and } \\
\text { economical }\end{array}$ & $\begin{array}{l}\text { Business activity(volume of commodity turn over, } \\
\text { speed of tunrover of commodity supplies, structure } \\
\text { of commodity turnover); profitability(commodity } \\
\text { turnover, charges of turnover, productive funds, } \\
\text { labour resources, assets and property asset); } \\
\text { liquidity and solvency }\end{array}$ & 0,25 & & \\
\hline $\begin{array}{l}\text { Informational } \\
\text { policy }\end{array}$ & $\begin{array}{l}\text { There is forming and development of } \\
\text { communicative public relations; development } \\
\text { and progress of standards of corporate style, } \\
\text { improvement of web site; providing of transition } \\
\text { from a paper to the electronic transmitters of } \\
\text { information in circulation of documents }\end{array}$ & 0,2 & & \\
\hline $\begin{array}{l}\text { Technical } \\
\text { supplement }\end{array}$ & $\begin{array}{l}\text { Level of providing an organizational technique; } \\
\text { presence of information-calculating center; } \\
\text { presence of technical equipments of information } \\
\text { transfer }\end{array}$ & 0,15 & & \\
\hline $\begin{array}{l}\text { The } \\
\text { administration } \\
\text { of the workforce }\end{array}$ & $\begin{array}{l}\text { Skilled planning and organization of set of } \\
\text { personnel; evaluation and attestation of workers of } \\
\text { enterprises; efficiency of management a personnel } \\
\text { (fluidity of personnel, labour productivity, net } \\
\text { income, is per employee) }\end{array}$ & 0,2 & & \\
\hline $\begin{array}{l}\text { Innovational } \\
\text { activity }\end{array}$ & $\begin{array}{l}\text { Amount of the inculcated technological } \\
\text { innovations, presence of own innovative } \\
\text { developments and NDDKR; amount of the } \\
\text { inculcated organizationally-administrative } \\
\text { innovations }\end{array}$ & 0,2 & & \\
\hline \multicolumn{4}{|l|}{ Subtotal, $\mathbf{S}_{\text {ef }}$} & $\Sigma$ \\
\hline
\end{tabular}

Note: *maximum point -5

In the process of information collection and aggregation for an enterprise performance appraisal, the experts, at first, choose the factors of ascendancy. According to the results of investigation of their dominance on organizational culture it is given finding on reasonability of their grouping with the view of more complete identification of the existent reserves of economic growth what can be in the form of the consistent matrix $[1$, p. 78$]$.

Objective evaluation gives the complex analysis of the estimated figures measurement results in accordance with the unified scale [17]. Using data of the tables we can define the criteria of an enterprise performance appraisal and the level of organizational culture excellence, and thus the life cycle stage by building the matrix of life cycle staging. Clear definition of the life cycle organizational culture allows us to find weaknesses betimes, develop an implementation program for their early correction and forecast the vectors of their future development. 
Appraisal worksheet of trade enterprise organizational culture excellence level

\begin{tabular}{|c|c|c|c|}
\hline Components & $\begin{array}{l}\text { Criteria of } \\
\text { validity } P_{j}\end{array}$ & $\underset{T_{j}{ }^{*}}{\text { Estimate }}$ & $\begin{array}{c}\text { Significance of } \\
\text { the factors } \\
\lambda_{j}=P_{j}^{*} T_{j}\end{array}$ \\
\hline $\begin{array}{l}\text { Attributes of organizational culture, public relations, } \\
\text { marketing and advertisement }\end{array}$ & 0,25 & & \\
\hline Associative space & 0,13 & & \\
\hline $\begin{array}{l}\text { Image, individuality, perception of the organizational } \\
\text { culture }\end{array}$ & 0,22 & & \\
\hline Service level & 0,22 & & \\
\hline Talent management & 0,18 & & \\
\hline \multicolumn{3}{|l|}{ Subtotal Sdb } & $\Sigma$ \\
\hline
\end{tabular}

Note: *maximum point -5 .

The refore, it makes sense to consider the defining of organizational culture life cycle level through the example of the well-known retail enterprises in Ukraine. Wholesale and retail enterprises are in everyday demand and their activity is of highly liquid. For this reason, it is actually to define their organizational culture life cycle level. Retail sales growth rate was at the level of 12.9\% in January-September 2015 and in the same period in 2014, thus the turnover rate in monetary value was UAH 651.2 mld. in 2014 and UAH 735 mld. in 2015 . However, if we liken unto the rates considering comparable prices, the decrease was $22.3 \%$.

Ukrainian retail market showed domination of orderly marketing on disorderly one during 2008-2012. If orderly marketing share was 55\% of total retail turnover volume in 2008 , then market share trends changed in 2014: disorderly marketing share was increased to $51.5 \%$ and the orderly one was decreased to $48.5 \%$. During the first six months of 2015 it was opened 140 food chain stores in Ukraine whereas during the same period of the last year it was opened 211 stores, the statistics was given to Liga.net portal by the investigative company GT Partners. Leaders in growth rate was also changed. This year the top list is headed by Fozzy Group what has been opened 15 new corner stores Fora and 5 supermarkets Silpo. Retailer has become the only of the biggest players what has opened more stores than in the first half of the year 2014 (11).

According to the information of the consulting company «EY», the following retail enterprises were actively operated in Ukraine in 2015: "Auchan Ukraine Hypermarket» LTD, «Metro Cash\&Carry Ukraine» LTD, «Retail Trade» LTD (chain of supermarkets «Furshet»), «FOZZY FOOD» LTD (chain of supermarkets «Silpo»), «Epitsentr K» LTD, «NOVUS Ukraine» LTD, «Omega» LTD (chain of stores "Varus»). $48 \%$ of retail market belongs to the biggest Ukrainian brands. Herein the competition takes place among the economic entities what can be roughly divided into the following groups: enterprises what are the part of international group of companies, trade enterprises what work in some regions of Ukraine and enterprises of local brands owners and unbranded stores.

In the order to determine the level of life cycle organizational culture it was interviewed 820 customers who visited retail enterprises in Ukraine in 2015. Each of them rated top stores of the retail market: «Auchan Ukraine Hypermarket» LTD, «Metro Cash\&Carry Ukraine» LTD, «Retail Trade» LTD, «FOZZY FOOD» LTD, «NOVUS Ukraine» LTD. Respondents defined the main criteria of organizational culture excellence (fuel quality and costs, quality of customer service, location, additional services in a store, cleanness, politeness and appearance of personnel, in-store design, chain im- 
age) using the scale: very good (9-10 points), good (7-8 points), middling (5-6 points), bad (3-4 points), very bad (1-2 points).

According to the response results of the managers of the retail enterprises, the operating efficiency appraisal (max - 5 points, min - 1 point) and organizational culture efficiency level (max - 5 points, min - 1 point) forms have been worked. Generalized results of organizational culture appraisal is given in the table 3 .

Table 3

Appraisal of retail enterprises organizational culture in Ukraine

\begin{tabular}{|c|c|c|c|c|c|}
\hline Criteria & $\begin{array}{c}« \text { Metro } \\
\text { Cash\&Carry } \\
\text { Ukraine» LTD }\end{array}$ & $\begin{array}{c}« F O Z Z Y \text { FOOD» } \\
L T D\end{array}$ & $\begin{array}{c}\text { «Auchan Ukraine } \\
\text { Hypermarket»LTD }\end{array}$ & $\begin{array}{c}\text { «Retail Trade» } \\
\text { LTD }\end{array}$ & $\begin{array}{c}\text { «NOVUS } \\
\text { Ukraine»LTD }\end{array}$ \\
\hline \multicolumn{6}{|c|}{ Results of customers expert questionary } \\
\hline Products quality & 7,8 & 7,72 & 8,65 & 8,87 & 7,77 \\
\hline $\begin{array}{l}\text { Customer service } \\
\text { quality }\end{array}$ & 7,96 & 6,18 & 8,44 & 8,17 & 7,74 \\
\hline Costs of products & 6,93 & 5,98 & 8,94 & 8,14 & 6,75 \\
\hline Location & 7,73 & 7,23 & 9,55 & 7,31 & 7,71 \\
\hline $\begin{array}{l}\text { Additional services } \\
\text { in a store }\end{array}$ & 7,98 & 5,32 & 7,92 & 8,8 & 7,85 \\
\hline Store cleaness & 6,97 & 6,12 & 7,93 & 8,71 & 7,88 \\
\hline $\begin{array}{l}\text { Personnel politness } \\
\text { and appearance }\end{array}$ & 7,2 & 6,94 & 7,33 & 8,02 & 6,7 \\
\hline In-store design & 7,71 & 5,61 & 7,62 & 8,78 & 7,02 \\
\hline Chain image & 7,87 & 5,84 & 9,62 & 8,83 & 8,11 \\
\hline \multicolumn{6}{|c|}{ Results of retail managers expert questionary } \\
\hline $\begin{array}{l}\text { Appraisal of } \\
\text { organizational } \\
\text { culture efficiency } \\
\text { level }\end{array}$ & 4,51 & 3,12 & 4,89 & 4,77 & 4,42 \\
\hline $\begin{array}{l}\text { Appraisal of } \\
\text { enterprise } \\
\text { operating } \\
\text { efficiency level }\end{array}$ & 4,67 & 3,23 & 4,81 & 4,24 & 2,81 \\
\hline
\end{tabular}

* Calculated according to the customers and managers interview data what was held in the trade enterprises of Ukraine in the I quarter of 2016.

The results of research show the high level of similarity almost at all criteria among the enterprises. In general, all of them have the mark "good». It is evidence that the customers do not see any essential difference among them. "Retail Trade» LTD (chain of supermarkets «Furshet») and "Auchan Ukraine Hypermarket» LTD have more evident positions due to active promotions. It is less recognized by the customers due to service level, personnel attention and external design. Thus, to increase the level of organizational culture, the enterprises have to produce the deals to enhance differentiation among the competitive trade enterprises. Furthermore, it is observed, that each of the retail enterprises stands on the different levels of life cycle (fig. 1). 


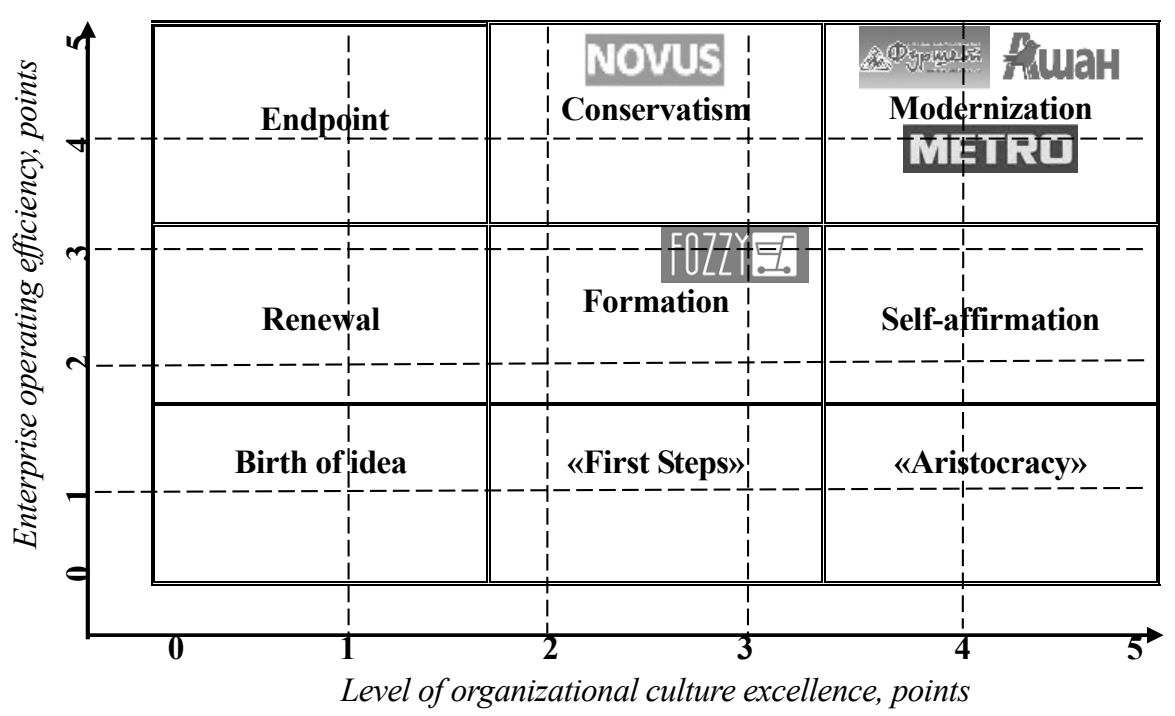

Fig. 1. Identification matrix of organizational culture life cycle level of the retail enterprises in Ukraine

\footnotetext{
* Calculated according to the data of expert managers interview what was held
} in the trade enterprises of Ukraine.

Consequently, organizational culture of «Auchan Ukraine Hypermarket» LTD, «Retail Trade» LTD and "Metro Cash\&Carry Ukraine» LTD is in the level of modernization what is confirmed by its ideal situation. There has been observed positive development of system of values for the customers and people, good quality of fuel, complex approach to services. Clear definition of life stage of a retail enterprise organizational culture life cycle allows to reveal deficiencies in time and to develop plan of actions for their removal, and, what is more, to forecast vectors of the future development. That is why, such enterprises as «FOZZY FOOD» LTD and «NOVUS Ukraine» LTD need to form organizational culture growth strategies. The following points can be referred as advantages of the growth strategy: risks minimization, product promotion in the market and novelties appearance. As the result of the performed research of retail enterprises positioning in Ukraine we think it is necessary to pay attention on the following factors while organizational culture improving and updating: formation of business ideas, market analysis, creating a quality product/ service, identification and individualization of a product, advertising communications, formation of the importance of ideology in an enterprise, loyalty winning, strengthen of organizational culture idea in the customers mind, faith of customers in brand value, further business management.

Conclusions. Concept of organizational culture life cycle has the following advantages: effective organizational culture compared to the product is easy adopted to innovation processes; it is clearly described by quantity parameters that reflect the stage of business life cycle. That is why it s offered methodological tools of matrix construction staging life cycle in the context of strengthening competitive advantages. Given recommendations will provide enterprise with the effectiveness of economic activity and level of excellence by achieving the proper level of the business life cycle. Practical implementation helps to increase controllability in-organizational processes and effectiveness of business management.

Modern age is characterized by rocketing development of globalization processes that raises new challenges in front of the community and at the same time opens new opportunities before it. Further researches of organizational culture life cycle conception are to be directed on development of analytical information system for retail business management. 


\section{Bibliography}

1. Білявська Ю.В. Матричний підхід до визначення життєвого циклу бренду / Ю. Білявська // Вісник Київ. нац. торг.-екон. ун-ту. - 2015. - № 4. - С. 68-80.

2. Гайдай Ю.В. Методичні рекомендації визначення стадії життєвого циклу організаційної культури підприємств торгівлі / Ю.В. Гайдай // Бізнес-інформ. - 2013. - № 1 (420) C. $164-167$.

3. Захарчин Г.М. Механізм формування організаційної культури машинобудівного підприємства: [монографія] / Г.М. Захарчин. - Львів: Вид-во нац. ун-ту «Львівська політехніка», 2009. $-276 \mathrm{c}$.

4. Ипатов С.А. Организационная культура: концептуальные модели и методы диагностики / С.А. Ипатов // Вестник Москов. гос. ун-та, Психология. - 1997. - № 4. - С. 4-10.

5. П’ятницька Г. Т. Управління розвитком організаційної культури торговельного підприємства / Г. П’ятницька, Ю. Гайдай, А. Предєін // Вісник Київ. нац. торг.-екон. ун-ту. 2013. - № 3. - С. 17-31.

6. Соломанидина Т.О. Организационная культура компании: учеб. пособие. / Т.О. Соломанидина. - 2-е изд., перераб. и доп. - М.: ИНФРА-М, 2011. - 624 с.

7. Тихомирова О.Г. Организационная культура: формирование, развитие и оценка / О.Г. Тихомирова. - СПб.: Изд-во С.-Петерб. гос. ун-та ИТМО, 2008. - 154 с.

8. Харчишина О.В. Діагностика організаційної культури підприємств / О.В. Харчишина // Наукові праці нац. ун-ту харч. техн. - 2010. - № 36. - С. 124-129.

9. Харчишина О.В. Економічні та організаційно-культурні проблеми розвитку харчової промисловості / О.В. Харчишина // Інноваційна економіка (ТІАПВ). - 2009. - № 2 (12). C. $119-123$.

10. Brown A. Organization Culture. - London: Pitman Publiching, 1995. - 324 p.

\section{References}

1. Biliavs'ka Yu.V. Matrychnyj pidkhid do vyznachennia zhyttievoho tsyklu brendu. Visnyk Kyiv. nats. torh.-ekon. un-tu., 2015, no. 4, pp. 68-80.

2. Hajdaj Yu.V. Metodychni rekomendatsii vyznachennia stadii zhyttievoho tsyklu orhanizatsijnoi kul'tury pidpryiemstv torhivli. Biznes-inform. 2013, no. 1 (420), pp. 164-167.

3. Zakharchyn H.M. (2009). Mekhanizm formuvannia orhanizatsijnoi kul'tury mashynobudivnoho pidpryiemstva. L'viv, Vyd-vo nats. un-tu “L'vivs'ka politekhnika", $276 \mathrm{p}$.

4. Ipatov S.A. Organizacionnaja kul'tura: konceptual'nye modeli i metody diagnostiki. Vestnik Moskov. gos. un-ta, Psihologija, 1997, no. 4. pp. 4-10.

5. P'iatnyts'ka H., Hajdaj Yu., Prediein A. Upravlinnia rozvytkom orhanizatsijnoi kul'tury torhovel'noho pidpryiemstva. Visnyk Kyiv. nats. torh.-ekon. un-tu, 2013. no. 3, pp. 17-31.

6. Solomanidina T.O. (2011). Organizacionnaja kul'tura kompanii. Moscow, INFRA-M, 624 p.

7. Tihomirova O.G. (2008). Organizacionnaja kul'tura: formirovanie, razvitie i ocenka. SanktPeterburg, Izd-vo S.-peterb. gos. un-ta ITMO, 154 p.

8. Kharchyshyna O.V. Diahnostyka orhanizatsijnoi kul 'tury pidpryiemstv. Naukovi pratsi nats. un-tu kharch. tekhn, 2010. no 36, pp. 124-129.

9. Kharchyshyna O.V. Ekonomichni ta orhanizatsijno-kul'turni problemy rozvytku kharchovoi promyslovosti. Innovatsijna ekonomika (TIAPV), 2009, - no. 2 (12), pp. 119-123.

10. Brown A. (1995). Organization Culture. London, Pitman Publiching, 324 p.

Проаналізовано підходи до трактування сутності поняття організаиійної культури. 3 апропоновано авторську конщепцію визначення стадї̈ життєвого ијиклу організаційної культури на підприємстві торгівлі. Методами експертного оцінювання визначено групи щеоо визначення ефективності діяльності підприємства та рівня досконалості організаційної культури. Визначено шилях формування збалансованої організачійної культури. Подано зведені результати 
оцінки чинників організаційної культури та алгоритм методичного підходу до програми формування збалансованої організаційної культури підприємства торгівлі. Сформовано основні рекомендації підвищення результативності діяльності підприсмств торгівлі шляхом удосконалення організаційної культури.

Ключові слова: життєвий цикл, організаційна культура, рітейл, підприємство торгівлі, матриця, збалансований.

Проанализированы подходы к трактовке сущности понятия организачионной культуры. Предложена авторская кониепџия определения стадии жизненного иикла организаџионной культуры на предприятии торговли. Методами экспертной оценки определены группы по определению эффективности деятельности предприятия и уровня соверменства организачионной культуры. В данной статье определены пути формирования сбалансированной организачионной культуры. Представлень сводные результаты оченки факторов организационной культуры и алгоритм методического подхода к программе формирования сбалансированной организационной культуры предприятия торговли. Сформированы основные рекомендации по повышению результативности деятельности предприятий торговли путем совершенствования организационной культуры.

Ключевые слова: жизненный цикл, организационная культура, ритейл, предприятие торговли, матрица, сбалансированный.

Одержано 3.07.2017. 